\title{
Constructing a More Open and Balanced Business News Agenda: International Narratives of China's Belt \& Road Initiative
}

$$
\text { Forum }^{*}
$$

\author{
QIAN Jingjing \\ University of International Business and Economics (UIBE), Beijing, China
}

\begin{abstract}
Due to the historical reasons, the global press has long been dominated by the Western community along with the other institutions such as media outlets, government agencies as well as research entities, in spite of the rising tendency presented by the new power bloc such as BRICS. It is important to differentiate the inspiring reporting characteristics in covering major events like this forum from those that still rely on the old reporting pattern and ideological mindset. Based on the previous scholarship on China's business communication and its relevance to the country's international communication in an ever-complicated international press environment, this study aims at working out the frame feature of the international business reporting on the Belt and Road Initiative Forum that took place in mid May, 2017. By offering a one-on-one analysis on the most representative piece respectively from Financial Times, Reuters, Nikkei Asian Review and Al-Jazeera, the study figured out the journalistic frame style of those media reporting on the event and on China's initiative itself. Therefore, the study aims to map out the reporting strategies for the similar emerging market countries such as BRICS accordingly.
\end{abstract}

Keywords: business news agenda, international communication, Belt and Road Initiative

Within the backdrop of the major western powers taking critical social-political turns such as Brexit series and Donald Trump's controversial policies, international communication expects to witness more convoluted global political dynamics. China, one of the most represented in the global business activities, is paradoxically among the most under-represented by the global press. Feeling difficult to decipher the logic of the world's production chain, western media tend to frame China's economy as institutionally challenged and conflicted. Discussion on economics is different from the one on politics and ideology. Every major change it undergoes will have significant effect on public opinion. The global attention has taken an East-and-South turn to figure out what China's stand and attitude will be during this new era.

Over the past years, Beijing has been incessantly trying to optimize its economic structure. On the international stage, the country has also geared up taking more responsibilities. From G20 Hangzhou Summit to President Xi's Davos speech, China has drawn more and more global attention within the economic arena. One of its biggest hits would be Belt \& Road Initiative Forum that China hosted this May. However, China's economic campaigns still do not have much saying on the economy discourse by the international press with a

\footnotetext{
*Acknowledgement: This research was supported in part by a grant from the University's New Faculty Grant Program.

QIAN Jingjing, Director, Business Journalism Undergraduate Program; Director, Research Center of International Business Journalism, School of International Studies, University of International Business and Economics.
} 
more balanced approach in journalistic practice. It is important to work out the relationship between the host-country diplomacy and the New Silk Road on the stage of international press.

Based on the previous scholarship on China's business communication and its significance for the country's international communication, this study intends to work out the framing features of the international business reporting on Belt \& Road Initiative Forum. From a global perspective, Financial Times, Reuters, Nikkei Asian Review as well as Al-Jazeera all serve as the premium news outlets from different continents; each of them has produced pieces on Belt \& Road Forum. What kind of narratives do these reports present? The study aims to map out the improvement media strategies for the similar emerging-market countries such as BRICS bloc accordingly. Taking the frame-feature analysis approach, the study examines the sampled stories and editorials respectively from the four aforementioned media. Five framing-analysis dimensions including issue, source, tone, main body and narration style adopted by the previous studies are used to analyze the chosen reports.

\section{The Financial Times: Game Theory on the Western Behalf}

Together with The Times, The Daily Telegraph and The Guardian, Financial Times is one of the four major newspapers in Britain. It is among the best print media and financial media in the world. Defined as elite press, Financial Times aims to provide global business information, financial analysis as well as in-depth comments. The named-after stock index by this paper has become the benchmark of the global economy. This study used "Belt and Road" as the key word to search among all the stories on the official website and then had 20 results, in which there are six stories directly related to this forum. This study selected the most balanced and most open-ended one as the research object. The headline is "One Belt, One Road - and many questions".

The article is the special editorial focusing on the Belt \& Road Initiative, representing the media's innate attitude towards the topic. The editor's note clearly states the viewpoint from the paper that The Belt \& Road is expected to achieve substantial favor which largely depends on China's goal in launching this policy in the first place.

In the beginning, the editorial outlines the broad backdrop of the current global economy. Trump's administration has caused the US withdrawal from the world's trade leader. The author maintains that the Chinese leader who has therefore rolled out The New Silk Road policy had regarded this trend as the opportunity. The move has been implementing infrastructure construction connecting China, Central Asia, and Africa; it is regarded quite "ambitious". The author also points out that there is about 900 billion US dollar investment for the project with most of the money coming from Chinese banks and credit funding. The author has used two words, "hope" and "worry", to conclude the attitude from the forum participants and also compared this investment move from China with the western powers when they were emerging, pointing out China's intent is more than market expansion. It wants to enlarge its political influence.

Next, from the host country's financial system, capacity exports and expected revenue, the author estimates that The Belt and Road will encounter difficulty in execution and little possibility in paying back the loan invested, with the linkage between this negative outlook and China's credit rating. The author also maintains that the very goal of this new silk-road initiative is to deepen its regional hegemony. It is also pointed out that those targeted countries would be reluctant to accept the loan given China has too many strings attached. The paper calls for the careful examination of the specific projects, such as the extent of Chinese enterprises' participation as well as the degree of being tapped into once built up. The author insists that China is "trying to 
export its own economic imbalances while buying regional leadership" if it can't answer those questions.

It is worth noting that this editorial has not linearly vetoed the meaning of Belt and Road Initiative. The author has mentioned that the project can help many countries with their infrastructure construction, so it can improve international trade with substantial effect. However, it can be clearly seen that Financial Times holds a quite skeptical attitude towards the initiative. On one hand, it feels reluctant to acknowledge China's economic potential and trade capacity. One the other, three important points could be drawn from the second half of this article: first of all, China's goal is suspicious; secondly, borrowing countries will have difficulty paying back; thirdly, China's political agenda is alarming. From all the above-mentioned reasoning, it can be seen that Financial Times holds the attitude of suspicion and light ridicule by taking the approach of political-economic game theory.

\section{Reuters: Informative from Geopolitical Stance Mixed with Doubt}

Reuters is among the most prestigious business news outlets in the world. As a premium news agency, it covers economy, politics, society and so forth, with a particular beat on business coverage. It is often regarded as the most important news source for many news organizations around the globe. This study conducted the similar approach and chose a story with the headline of "Xi Jinping says the rejection of protectionism is part of what 'One Belt, One Road' is about".

From the angle of the structural feature, the headline points at exactly what the leader of China wants to emphasize with the special focus on its attitude towards protectionism, which, since Trump took office in early 2017, has been one of the major threats of the world economy.

In the lead, Reuters stresses that $\mathrm{Xi}$ is trying to get more multi-lateral organizations to join the Initiative with the emphasis on the importance of fighting against protectionism in order to achieve global economic development. In the nut graph, the author extends the lead by introducing in which context Xi proposed the idea and which are the multi-lateral institutions he wanted to join China's grand project. Then, in an independent paragraph, the author introduces the scale and scope of this project and in the end it stresses that China has used this to form a very sharp contrast against Trump's “America First" mindset in policy-making process.

Then, the reporter quotes directly from Xi's address to emphasize that China is all for policy coordination and against zero-sum game in the era of globalization by saying "reject beggar-thy-neighbor practices". The reporter also mentions that $\mathrm{Xi}$ is making this statement to caution against another chance of global financial crisis. Then, in the third quote, the author tells the audience that Xi strongly advocates for openness, cooperation and inclusiveness in the practice of world economic and business activities.

After the series of quote from $\mathrm{Xi}$, the reporter then starts commenting on the special point of this big project that China is putting forward to. The reporter points out that Belt and Road Initiative is "China's answer to the Trans-Pacific Partnership (TPP) deal", stressing its relevance to TPP which had been proposed by Obama and then was abandoned by Trump for the latter's "America First" ideology. The reporter then uses both indirect and direct quotes to further expand on what Xi tries to stress in the remark that the world and globalization is experiencing "headwinds" and it is a world of "interdependency". After the quotes, the story states that leaders from 29 countries attended the event as well as those representing Washington Institutions such as IMF and World Bank.

Last but not least, the reporter mentions the "unease" from the viewpoint of the West. They see this project as China's attempt to promote its own influence; more transparency and access are called for during the 
practice of this project. In the end, the story from Reuters closes with a tone of light concern and doubt, with its critical analysis from the point of geopolitical stance.

\section{Nikkei: Media Agenda with Suspicion and Inhibition}

Defined as the most important business media platform in Japan, Nikkei covers economy, politics, society, culture and so forth, with the emphasis on business coverage. It has been quite famous for its economic policy and capital market. Nikkei Asian Review is its English-language reporting platform focusing on Asia. With the similar approach, this study searched its website and had 18 articles related to the topic. Interestingly, Nikkei has a special issue on Belt and Road Initiative with the name of "New Silk Road Summit in Beijing". This study again picked out the most balanced and opened headlined story as the research object with the title of "China's Belt and Road forum brings bold promises, mixed results".

From the angle of news structural feature, this story's headline clearly states its attitude: jealous and suspicious. The editor's note further expands that by noting, "high-profile projects mask uncertain future for economic sphere".

In the lead, the author tells the readers two important two-folds of meaning. First, China taps into Belt \& Road International Conference to promote its large-scale infrastructure construction project. Second, private sectors have turned a cold shoulder as the treatment. Next, the report has a nut graph consisting of numbers to describe the size of participants, entailed countries as well as the number of national leaders. Then, the reporter objectively introduces the united statement signed on the roundtable summit on May 15th, as well as the call for opened economy and against trade protectionism.

From the perspective of theme development and reporting focus, the story uses one subheading "strengthening connections" to focus on one major theme. In this part, the author introduces the investment in Indonesia's high-speed train project as well as the progress of the nuclear reactor construction in Argentina. Also, the report emphasizes the Chinese leaders' announcement of total of 780 billion RMB ( $\$ 113$ billion) in additional funding in the forms of an increase in the scale of the country's Silk Road fund and loans from policy banks.

It is essential to notice that this story had taken an interesting turn of tone since here: from coverage on international trade to taking a guess on host country's political agenda. The author notes that China intents to "broaden its sphere of economic influence and win allies around the world" and "hopes the benefits the initiative brings will turn this diverse group into a loose union". Then, the author offers an in-depth introduction to China's private sector by telling readers that private sector owners hold negative attitude towards the initiative thinking the risk outweigh the benefit.

It is worth examining that here the story used the only one source of the entire story. What's more, this source is anonymous: "An official at a development bank said there are very few suitable infrastructure projects in developing nations the institution could invest in". At the end, the author collectively introduces the basic attitude towards China's project, which is to keep a close watch, in order to see whether the initiative "can contribute to the region's sustainable development".

From the angle of reporting tone, this story serves as another example of "interesting media frame" which can be illustrated as seemingly neutral yet implicitly negative. Specifically put, the story has made itself seem quite objective and neutral in the most important parts such as title, lead and nut graph. However, in the later part of the report, namely the bottom half of the inverted pyramid, the author has started to map out its skeptical 
and worried attitude from the angles of political agenda and the project's feasibility. This story from Nikkei Asian Review closes with a tone of suspicion and inhibition, representing a peculiar invisible media agenda in reporting China's Belt and Road Initiative.

\section{Al-Jazeera: Skeptical Attitude Balanced by Objective Coverage}

Al-Jazeera is largely renowned as "the CNN in the desert". Located in the oil exporting power Qatar, the TV station is funded by the affluent royal family. Tapping into its proximity within the disputed area, Al-Jazeera has enjoyed its advantage in reporting Mid-east affairs with the goal of building up one of the world-famous media platforms. Having hunted quite a few number of outstanding journalist talents from the Arabic channel from BBC, the station has excelled in terms of management system, funding resources, and unique geo-political advantage. In less than two decades, it has quickly become a phenomenon media outlet in the world with the strengths in location, media convergence and in-depth reporting.

This study has included Al-Jazeera's reports as the research objects as it is intended to form a comprehensive representative group for the global media together with the two aforementioned outlets from UK and Japan. The study has attained four reports from the keyword search from its website. Similarly, this study has chosen the most balanced and opened work whose headline reads "China's mission to reinvent the Silk Road".

It is easy to conclude that this story has a succinct and quite neutral headline introducing the subject and event, without any leading remarks as the two colleague outlets did. In the part of editor's note, the story briefly uses a sentence to break into Belt and Road Initiative's nature, which is to enhance the trading activities among three continents with over 3 billion's population. In the lead, the story introduces the caliber of the project being the largest oversea investment by a single country. In the nut graph, the reporter outlines the huge financial basis, numbers of countries involved as well as the details of its major infrastructure construction. Also, the story uses the word ultramodern to describe this trading corridor connecting the global market.

Nonetheless, in the following paragraphs, the story has expressed its basic attitude as skeptical. From the perspective of theme distribution and development, the story has not built up any subheadings. Instead, it has expressed the skeptical attitude with lots of details and small paragraphs. There exist two levels of analysis throughout the entire story. One is the suspicious tone and the other is the detailed narrative on the Pakistan project.

The report notes that this endeavor has been criticized due to many reasons surrounding "who really benefits". The author thinks that infrastructure will not necessarily bring about economic growth given the possibility of the entailed countries' inability of paying back the loan. What will happen if that happens? The report tries to layout that the year of 2013 is both the launching Belt and Road Initiative and also the slowing period of Chinese economy. The author points out that the international community has started to question the end of China's economic measure.

Also, in the next paragraph, the report briefly introduces the unfavorable tone from India, the US and Australia, as well as the support from Pakistan and New Zealand. In its introduction of Pakistan project, the reporter maintains "what happens to the local economy when all roads lead to Beijing" even if the country had occupies admittedly important location connecting Asia, Europe and Africa. From here, it can be regarded that the story has taken an interestingly skeptical attitude towards China and the nature and goal of Belt and Road Initiative. 
Then, the author has introduced the China-Pakistan trade corridor with \$55-billion investment. China is the largest financial source and aims to solve the technical problem of energy transformation problem for Islamabad. At the end of the report, the reporter describes his exclusive interview with the commerce minister Khurram Dastgir Khan. In his answers, it can be seen that Pakistani government's definition of its own economic overview. More importantly, when asked if he is afraid that Pakistan will be too dependent on China, Minister Khan told Al-Jazeera that fear and worry will expand when a country is about to open up as happened in China in the 1970s when the Reform and Opening-up first launched. He also emphasizes that China's initiative has brought more than roads, ports or airports in its traditional meaning, but rather something in dire need, which is energy. He points out that for Pakistan the expected benefit weighs a lot more than fear and worry.

From the angles of structural feature, theme distribution as well as tone towards China, it is easily to conclude the editorial characteristic of Al-Jazeera in its coverage. It has clearly expressed its skeptic view right from the beginning in its headline, lead and the nut graph, quite different from what Nikkei does, which is to have the attacking tone emerging from the second half of the story. As a whole, this piece still represents the standards of hardcore journalism: objective narrative of the truth and all-rounded introduction of different sides, with respects of its news sources and theme distribution. It has offered its readers a rather comprehensive picture of Belt and Road Initiative.

\section{Suggestions for Enhancing Global Business Communication}

With the inconsistent economic policy by Trump's administration, the US has withdrawn from the world leader in trading activities. This has paved the way for China telling the economic story to the outside world. In this special era featured by sluggish world economy and global protectionism, China held Belt and Road Forum calling for the New Silk Road Spirit, namely honoring peace, open and inclusive culture, learning from each other and mutual benefit. The initiative has established a brand new situation for enhancing the economic and trading collaboration as well as eliminating barriers and enjoying developing benefits. However, the international press has taken on a complicated look towards this initiative. Together with compliment, approval and admiration, reluctance, suspicion and alertness had also become the key words of the global media when covering the forum events. Based on the above analysis from the four global media outlets, the study tentatively offers the following suggestions for the future economic communication.

\section{Being the Major Source for the Major Advantage}

In the process of international communication for a special event, the host country's biggest advantage is its autonomy of information, resources as well as channel. Those important elements in information communication will play determining effect in fighting for international voicing right. When the foreign journalists are reporting on the event, they inevitably use the official announcement and attitude as important sources, which is the basic rule in journalistic practice. In this case, it would be quite vital for the host country to have clear viewpoint, effective news channel as well as efficient journalists. They will have a critical team-working impression, which will influence the foreign media's reporting structure. During the period of Belt and Road Forum, President Xi Jinping's keynote speech has achieved a tremendous effect in international communication, which is clearly represented in the reports from Nikkei and Al-Jazeera. These two media have seen their agenda setting heavily influenced by Xi's speech when their reporters are covering the event and the detailed measures to be taken by the Chinese government. 


\section{Dissolving Suspicion and Actively Responding to Inquiries}

As has been discussed before, being skeptical is the invasive viewpoint from all the four media stories. People are not sure about China's intent of launching this initiative in the first place, financial supervision capability and China's implementation into tiny details of all the entailed projects. They are also suspicious about the targeted countries' paying-back ability and whether they will end up benefiting. Between the lines of all these reports, it is clearly viewed the reasons behind these question marks. Some root from the journalists' lack of background knowledge of Belt and Road while some is explained by media's intentional distortion of truth in reporting this event by an emerging power.

Faced with this tendency, it is essential to work out and then list the most important inquiries from the international press, such as why China has set up this huge project with this amount of money spent. Also, it had also been inquired that if China's initiative can help the targeted countries with their economic development, and if the project will put into place the creation of open and mutual-benefiting trade pattern. The international communication will need to use detailed events, exact numbers and vivid graphics to actively respond various inquiries from the global community.

For example, as for the question whether Belt and Road and its investment can promote the well being of the related countries and areas along the routes, it is important to address that investment from China's state-owned enterprises has created 330,000 jobs in those areas. Also, these companies have employed more than 380,000 people in their overseas works, among which the local employees account for $85 \%$. As the beginning section of the Eastern African railway, the Mombasa-Nairobi Railway will contribute more than 2\% of Kenya's GDP (Li, 2017). All the rumor and suspicion will end with truth. When faced with suspicion, it is important to actively respond and to clarify head-on.

\section{Collaborating and Competing with the Global Colleagues}

Admittedly, China has gained a remarkable economic momentum and position in today's world. Yet, China still needs to improve its international communication capability and related construction due to historical reasons. Even if it is the host, it does not necessarily mean that it has acquired all the skills needed for the job. China's international communication will go a lot further if there are more than Chinese media who are producing the voices.

In this regard, it is critical for Chinese international journalists to vigorously interact with the foreign media. On one hand, it is important to look outwards so as to understand the major intent and news frame of those international colleagues. So it would be easier to work out China's follow-up report to react or to refute. One the other hand, it is quite necessary to take advantage of media convergence's strength to interact with all the relevant international media by using the hash-tagging function to let them pay attention to what China has to say. It is also a good idea to continuously post the first-handed audio and video materials to provide the fundamental footages for the international media's reporting works so as to guide their reporting frame. By tapping into the advantage of being the host of a certain event, the international communication practitioners and researchers will need to actively collaborate and compete with the foreign colleagues.

All in all, the research concludes that media from Western countries still conduct a rather skeptical editorial attitude towards China's increasing influence. Reports from Japan have some interestingly constructed invisible agenda, suggesting the reluctance of confirming China's regional economic impact. Stories from the 
Mid-Eastern counterpart have a more balanced structure under the circumstance of proposing doubts on application of Beijing's ideas in terms of infrastructure construction and funding programs.

It is usually quite common to see China's mainstream media engage government-agenda dominance of content, citing source, tone and journalistic style with a few exceptions. Therefore, two approaches are proposed based on the results from this study. Firstly, China's mainstream international media should construct a very specific theme to leverage the stereotypical narratives. They could construct special columns and panels to specifically address the suspicion from outside the country. Secondly, they should extend their overly official agenda to a more pluralistic one by entailing different entities and employing diversified sources, tones, and styles. The endeavor is not just to fight for China's own interest, but also to alleviate the long-standing disadvantage in the international press, so as to build up a more open and balanced agenda for business reporting globally.

\section{References}

Al-Jazeera $\quad$ English. $\quad$ (2012). Corporate profile. $\quad$ Retrieved from http://www.aljazeera.com/aboutus/2006/11/2008525185555444449.html

Coyle, J. (2012). YouTube becoming major news source. Pew Study. Retrieved from http://www.huffingtonpost.com/2012/07/16/youtube-pew-news-source_n_1675123.html

Dubai. (2009). Obama tells Al Arabiya peace talks should resume. Retrieved from http://www.alarabiya.net/articles/2009/01/27/65087.html

Feuilherade, P. (2003). Profile: Al-Arabiya TV. Retrieved from http://news.bbc.co.uk/2/hi/middle_east/3236654.stm

Heritage, T. (2013) Putin dissolves state news agency, tightens grip on Russia media. Retrieved from http://mobile.reuters.com/article/idUSBRE9B80I120131209?irpc=932

Krane, J. (2006). Al-Jazeera says its English-language news channel will launch Nov. 15. Retrieved from http://poststar.com/news/al-jazeera-says-its-english-language-news-channel-will-launch/article_89c63833-6251-5415-82b7-0 0cb431924eb.html

Lariokhin, T. (2005). Russia Today TV to make unique contribution to global information-German expert. Retrieved from http://en.ria.ru/society/20050607/40486831.html

Li, D. (2017). The state-owned enterprises' B\&R imitative investment stimulates 330K jobs. The Beijing News. May 9, 2017, A06.

Mândrăşescu, V. (2013). BRICS countries are building a "new Internet" hidden from NSA. Retrieved from http://voiceofrussia.com/2013_10_28/BRICS-countries-are-building-a-new-Internet-hidden-from-NSA-7157

Martinez, J. (2012). Pew: Russia Today, fox news lead the pack on YouTube. Retrieved from http://thehill.com/blogs/hillicon-valley/technology/238157-pew-rt-fox-news-are-top-sources-of-popular-news-videos

Pascali, U. (2013). The BRICS "independent Internet" cable. Defiance of the "US-centric Internet". Retrieved from http://www.globalresearch.ca/the-brics-independent-internet-in-defiance-of-the-us-centric-internet/5350272

Qian, J. (2013). The rise of the rest for global communication: Possibly, or potentially? Retrieved from http://cgcsblog.asc.upenn.edu/2013/10/21/the-rise-of-the-rest-for-global-communication-possibly-or-potentially/

Radia, K. (2011). Sec. of state Hillary Clinton: Al Jazeera is "real news", U.S. losing "information war". Retrieved from: http://abcnews.go.com/blogs/politics/2011/03/sec-of-state-hillary-clinton-al-jazeera-is-real-news-us-losing-information-war

Rizvi, H. (2010). MEDIA: Foreign news channels drawing U.S. viewers. Retrieved from http://www.ipsnews.net/2010/01/media-foreign-news-channels-drawing-us-viewers

RT. (2013). Putin warns against "illegal” military action in Syria, bypassing UNSC. Retrieved from http://rt.com/news/putin-syria-interview-ap-387 